\title{
ANEMIA PADA IBU USIA 17-35 TAHUN DI DAERAH 'REPLETE’ ENDEMIK DEFISIENSI IODIUM
}

\author{
Basuki Budiman ${ }^{1}$ Rosmala Dewi ${ }^{1}$ dan Sri Muljati ${ }^{1}$ \\ ${ }^{1}$ Puslitbang Gizi dan Makanan Depkes RI, Bogor
}

\section{ABSTRACT
ANEMIA OF CHILD BEARING AGE MOTHERS 17-35 YEARS OF AGE IN ENDEMIC IODINE 'REPLETE' AREA

Iron Deficiency Anemia (IDA) as well as lodine Deficiency Disorder (IDD) both have adverse effects on cognitive and neuropsychomotor, and adverse pregnant outcomes. Both iron and iodine have role on nuero development. Iron interact with iodine through the activity of thyroid peroxidase (TPO), an iron-dependent enzyme. IDA in iodine replete area (IRA) have not been reported. Assesments IDA (Hb), free thyroxine (fT4), Thyrotropin hormone (TSH) of reproductive mothers 17-35 years of age were conducted in IRA and non-endemic deficiency iodine area (NEDIA). Casual iodine urin concentration (UIC) of school age children was also assesed to confirm iodine endemicity of study area. Analysis of risk for anemia according to iodine status and correlation hemoglobin and thyrotropin were performed. The study area was confirmed to be non endemic iodine deficiency (UIC criteria). Median EIU were 242 (24-880) $\mu \mathrm{g} / \mathrm{L}$ in IRA and 211 (44$387) \mu \mathrm{g} / \mathrm{L}$ in NEDIA respectively. Proportion of EIU less than $100 \mu \mathrm{g} / \mathrm{L}$ in IRA were $5.0 \%$ and in NEDIA $1.2 \%$. Proporsion of EIU greater than $300 \mu \mathrm{g} / \mathrm{L}$ were 29.6 dan 24.7 persen respectively. The results indicated that study areas were no longer endemic iodine deficiency and the people where they live consumed iodine tend to excess. These situation may effect on thyroid function as indicated by suppressed TSH and fT4 in normal range. Those two thyroid function parameters significantly different in the IRA and NEDIA. The everages serum concentration of TSH in the study area were $1,96(1,56-2,36)$ in IRA compared to $1,38(1,09-1,67) \mathrm{mUI} / \mathrm{L}$ in NEDIA(p=0,23); while fT4 were $1,29(1,14-1,44)$ and $0,98(0,90-1,05) \mu \mathrm{g} / \mathrm{dL}$ respectively. Hemoglobin serum concentration of mothers in those two area was not signicantly different; $12,45(12,19-12,71)$ in IRA compared to $12,21(11,96-12,46) \mathrm{mg} / \mathrm{dL}$ di NEDIA. Iron deficiency anemia was found $23,3 \%$ in IRA and $35,7 \%$ in NEDIA; however mothers in IRA have risk for anemia as big as mothers in NEDIA OR: 0,54(0,24-1,24). Analysis correlation (Spearman's) between TSH and Hb provided coefisient correlation Rho as much as 0.072 indicated very weak correlation between the two parameters. There were no difference in proportion of hypothyroidism in the two study areas (OR: $0,68(0,207-2,25)$. Although the proportion of iron deficiensi anemia (IDA) in IRA much less than the proportion in NEDIA; there were no relationship between IDA and lodine deficiency. Absorption of Fe in IRA may be more efficient than did in NEDIA. More studies are needed to confirm this finding.

Keywords: IDA, TSH, fT4, Hb, EIU, NEDIA, IRA

\section{PENDAHULUAN}

efisiensi mikronutrien (DVM) terutama defisiensi vitamin A (KVA), iodium (GAKI), anemia zat besi (AZB) khususnya defisiensi zat besi (DZB), Zink, asam folat merupakan masalah dunia.
Lebih dari dua milyar (33\%) penduduk dunia menderita DVM, yang secara langsung berpengaruh terhadap potensi intelektual dan secara tidak langsung berdampak pada produktivitas dan pembangunan nasional(1). Dua yang pertama adalah masalah DVM yang dihadapi oleh negara-negara yang berkembang; sedangkan masalah AZB tidak 
hanya oleh negara berkembang saja tetapi negara maju juga menghadapi masalah AZB terutama DZB. Di negara berkembang, DVM seringkali saling tumpang tindih terutama pada ibu hamil dan anak-anak. Kedua kelompok ini sangat rentan terhadap DVM terutama AZB dan $\mathrm{GAKI}^{(2)}$.

DVM di Indonesia sangat tinggi. AZB pada anak di bawah lima tahun (balita) sebesar 47 persen; pada WUS dan ibu hamil masing-masing 26,4 dan 40,1 persen. KVA secara klinis bukan masalah kesehatan masyarakat, namun proporsi dengan kadar vitamin A dalam serum kurang dari $20 \mu \mathrm{g} / \mathrm{dL}$ sebesar 50 persen. Proporsi GAKI (TGR dengan palpasi) sebesar 11,1 persen ${ }^{3}$.

Kurang-lebih setengah dari prevalensi AZB adalah DZB. Badan Kesehatan Dunia (WHO) memperkirakan proporsi penderita DZB di negara berkembang pada laki-laki dewasa sebesar 25 persen dan pada perempuan dan anak-anak sebesar 50 persen, sedang di negara maju pada perempuan dan anak-anak sebesar 7-12 persen. DZB menampilkan kinerja fisik buruk, menghambat perkembangan, melemahkan kognitif, berdampak buruk pada kehamilan dan bayi yang dilahirkan ${ }^{(1)}$. Pada suatu penelitian yang dirancang secara 'randomized control trial pada wanita usia subur (WUS, 18-35 tahun), disimpulkan bahwa status zat besi merupakan faktor penting yang berpengaruh terhadap kinerja kognitif. AZB berat berpengaruh terutama pada proses kecepatan; sedang DZB berpengaruh pada fungsi kognitif. Disimpulkan juga bahwa pengaruh DZB tidak terbatas pada perkembangan otak saja ${ }^{4}$. Risiko morbiditas, mortalitas dan melahirkan bayi dengan berat badan rendah (BBLR) pada ibu hamil penderita AZB meningkat. AZB berkaitan dengan mortalitas hanya jika AZB berat tetapi tidak pada AZB yang ringan dan sedang. Menurut Hess² (2003, disertasi) hubungan AZB dengan BBLR dan lahir terlalu cepat (tidak cukup bulan) belum dapat disimpulkan karena tidak cukup data. Demikian pula hubungan AZB dengan kematian neonatal dan perinatal. AZB yang berat dipercaya tidak hanya DZB saja, defisiensi mikronutrien lain juga terjadi. Jika
AZB terjadi pada anak usia 12-18 bulan akan menghambat pertumbuhan yang tidak dapat diperbaiki ${ }^{(1)}$; dan jika AZB disertai defisiensi iodium pada janin dan awal kehidupan, keduanya dapat menyebabkan retardasi mental dan motor ${ }^{(5,6)}$.

Gangguan akibat kekurangan iodium (GAKI) mempunyai spektrum luas dengan konsekuensi terberat adalah kretinism dengan besaran proporsi 3-10 persen. Sekitar 5-30 persen adalah penderita kelainan neuropsikologi seperti strabismus, bisu-tuli (deaf-mute), disarthria, disleksi karena cidera sebagian otak (some brain damage). Proporsi terbesar dari GAKI ini adalah kelainan metabolik yang berupa kehilangan energi karena hipotiroidism sebesar 30-70 persen. GAKI menjadi pemicu terjadinya kegagalan kehamilan seperti aborsi, bayi lahir mati dan kecacatan bawaan (congenital anomalies), gangguan pertumbuhan psikomotor (psychomotor defect). Jika defisiensi terjadi pada kehidupan awal dan anak-anak dapat meningkatkan risiko kematian perinatal, kematian anak dan retardasi mental dan perkembangan fisik ${ }^{(7)}$. Dampak yang sama juga ditemukan pada penderita AZB/DZB.

Dampak defisiensi iodium terhadap gangguan neuropsikomotorik telah banyak penelitian membuktikan hal tersebut baik pada binatang maupun manusia serta telah banyak diulas ${ }^{(8-16)}$, namun bukan berarti bahwa kelainan neuropsikomotorik merupakan dampak hanya kurang iodium. Zat gizi lain baik makro maupun mikro ternyata berpengaruh terhadap metabolisme iodium. Anak sekolah di daerah endemik defisiensi iodium yang tampaknya normal, setelah diintervensi dengan iodium, membaik proses informasinya, gerak motorik halus dan masalah penglihatannya ${ }^{(16)}$.

Defisiensi energi-protein menghambat metabolisme iodium melalui pengaruh defisiensi energi-protein pada sistem endokrin yaitu terhadap berat kelenjar, struktur histologi, dan fungsi kelenjar tiroid walaupun dalam jangka waktu yang cukup lama. Di Sudan, GAKI dilaporkan berkaitan dengan defisiensi protein-energi, KVA dan $A Z B^{(17)}$. Di Maroko, suplementasi vitamin A 
dilaporkan meningkatkan efikasi iodium ${ }^{(18,19)}$. Defisiensi selenium merupakan bagian tak terpisahkan pada enzim glutationperoksidase (GSH-Px) yang berpengaruh pada deiodinasi T4 menjadi $\mathrm{T}^{(20,21)}$. Konsentrasi Zinc, Copper (Cu), Mangan (Mn) Selenium dalam plasma, eritrosit dan urin berubah-ubah menurut status tiroid ${ }^{(22)}$.

Zat gizi besi (Fe) berkaitan dengan iodium. Walaupun mekanisme molekuler peran Fe dengan iodium belum begitu jelas, namun beberapa penelitian menunjukkan korelasi antara kedua mineral tersebut ${ }^{(17-19,23-}$ 24). Defisiensi Fe diduga berperan dalam metabolisme iodium dalam sel tiroid dan defisiensi Fe juga menurunkan efikasi profilaksis iodium. Sintesa hormon tiroid membutuhkan kehadiran $\mathrm{Fe}$ dan katalisa enzim tiroperoksidase (TPO, enzim yang bergantung pada zat besi). Defisiensi Fe berat menurunkan aktifitas TPO dan mengganggu sintesa hormon tiroid yang akhirnya menurunkan konsentrasi tiroksin dalam plasma ${ }^{(25)}$. Di samping itu, penanggulangan defisiensi gizi besi dilaporkan meningkatkan efikasi iodium di Cote d'Ivoire ${ }^{(19,26)}$.

Di masa lampau daerah endemik defisiensi iodium yang berat seringkali dijumpai di daerah yang sukar dijangkau, dalam arti bahan pangan dari luar masuk ke daerah tersebut, daerah yang penduduknya miskin bahkan seringkali penduduknya kurang gizi. Aborsi, keterlambatan gerak motorik, informasi pada daerah defisiensi iodium bukan tidak mungkin disebabkan oleh berbagai macam defisiensi gizi, tidak hanya iodium tetapi terjadi karena defisiensi gizi baik makronutrien maupun mikro. Sekarang dengan kemajuan transportasi dan informasi, daerah-daerah tersebut telah terbuka, ekonomi penduduk juga bertambah baik. Artikel yang merupakan bagian dari hasil penelitian 'Efek intervensi iodium secara masif terhadap kejadian hipertiroidi di daerah 'replete' endemis defisiensi iodium' ini menyajikan kajian anemia zat besi di daerah yang dulunya merupakan daerah (replete) defisiensi iodium yang berat.
Tujuan

Mempelajari hubungan anemia zat besi dengan konsentrasi serum tirotropin dan tiroksin bebas di daerah bekas (replete) defisiensi iodium

\section{BAHAN DAN CARA}

Penelitian ini dirancang secara potonglintang (kroseksional) dan dilaksanakan di Kabupaten Magelang, Jawa Tengah dan Kabupaten Ngawi Jawa Timur pada tahun 2005. Daerah ini dipilih karena pada masa lalu merupakan daerah endemik defisiensi iodium yang berat dan saat penelitian ini dilaksanakan merupakan daerah yang telah mengalami perbaikan.

Di tiap kabupaten, berdasarkan riwayat endemisitas defisiensi iodium tahun 1996 (secara palpasi, karena tidak diketahui data konsentrasi iodium dalam urin), dipilih empat kecamatan dengan endemisitas yang berbeda, yaitu kecamatan endemis defisiensi iodium berat/sedang dan kecamatan non endemik dan pada saat penelitian tidak lagi endemis.

Populasi adalah ibu dari pasangan usia subur (17-35 tahun ) yang tinggal di daerah 'replete' endemik defisiensi iodium. Partisipan adalah ibu dari pasangan usia subur (17-35 tahun ) yang tinggal di daerah 'replete' endemik defisiensi iodium di kabupaten Ngawi, Jawa Timur dan Magelang-Jawa Tengah. Di samping itu partisipan harus memenuhi kriteri berstatus menikah, telah di daerah penelitian paling tidak sejak tahun 1996. Partisipan juga tidak sedang menderita penyakit kronis yang dapat mempengaruhi kadar tiroksin, tidak sedang hamkil dan atau menyusui, tidak sedang haid dan sedang tidak menggunakan alat kontrasepsi yang berbasis hormon.

Data yang dikumpulkan meliputi serum darah untuk pemeriksaan hormon tirotropin (TSH) dan tiroksin bebas (fT4) dalam rangka penentuan status iodium secara biokimia; konsentrasi iodium dalam urin (EIU) anak sekolah untuk menentukan endemisitas daerah saat penelitian dilaksanakan sekaligus cerminan konsumsi iodium masyarakat setempat; kadar haemoglobin untuk menentukan anemia $(\mathrm{Hb}<12,0 \mathrm{mg} / \mathrm{dL})$. 
Partisipan secara fisik diperiksa kesehatannya oleh dokter umum. Darah diambil dari vena sebanyak $2,5 \mathrm{~mL}$ oleh petugas analis kesehatan. Specimen urin anak usia sekolah (6-12 tahun) dikumpulkan dalam kantong plastik dan kemudian dipindahkan sebanyak $5 \mathrm{~mL}$ ke dalam botol yang bebas iod dan telah diberi timol. Pemeriksaan TSH, fT4 dan EIU dilaksanakan di laboratorium GAKI, universitas Diponegoro, Semarang. Penentuan $\mathrm{Hb}$ dilakukan secara cyanmethomoglobin.

Di kabupaten yang terpilih, partisipan diseleksi dengan menggunakan daftar IBU PUS 17-35 tahun dari BKKBN tingkat Kecamatan/kabupaten setempat dan diperoleh kerangka sampling. Kemudian dengan menggunakan daftar random diperoleh sampel yang diinginkan. Untuk memperkecil area akan dilakukan pemilihan desa yang menurut pertimbangan petugas kesehatan/gizi setempat mengetahui riwayat endemisitas desa ybs. Kemudian desa tersebut dikonfirmasi dengan kemungkinan masih didapatkan monumen hidup atau tanda-tanda defisiensi iodium. Hal ini dilakukan untuk mempertajam daerah sasaran.

Pemilihan partisipan dilaksanakan dengan metode stratifikasi random sampling dengan penyesuaian banyaknya populasi (pps)

$$
\begin{aligned}
& \text { Rumus: } \quad \mathrm{n}=\underline{\mathrm{Z}}_{1-\alpha \alpha 2-2}^{2} \Sigma\left[\left\{\mathrm{N}^{2}{ }_{\mathrm{h}} \underline{\mathrm{P}}_{\mathrm{h}}\left(1-\mathrm{P}_{\mathrm{h}}\right)\right\} / \mathrm{W}_{\mathrm{h}}\right] \\
& \varepsilon^{2}\left(\Sigma N_{h} P_{h}\right)^{2}+Z_{1-\underline{\alpha} / 2}^{2} \Sigma N_{h} P_{h}\left(1-P_{h}\right) \\
& \mathrm{n}=\text { besar sampel yg diinginkan } \\
& \mathrm{h}=\text { strata, } 1-4 \text { (berat, sedang, ringan dan non endemik) } \\
& \mathrm{W}=\text { fraksi sampel yg dialokasikan untuk stratum } \mathrm{h} \\
& \mathrm{P}=\text { prevalensi } \\
& \mathrm{N}=\text { besar populasi } \\
& Z=95 \% \mathrm{Cl} \\
& \varepsilon=\text { presisi }=\text { simp estimasi teta thd teta pop }=0.05
\end{aligned}
$$

Dengan cara perhitungan ini dapat diketahui kebutuhan sampel sebesar 63 IBU PUS tiap kabupaten dan ditambahkan kemungkinan tidak bersedia menjadi ampel atau tidak dapat ditemui pada waktu kunjungan, sebesar 20 persen maka kebutuhan sampel tiap kabupaten sekitar 75 IBU PUS atau jumlah seluruhnya sebanyak 150 orang IBU PUS. 
Variabel pokok dan cara pengumpulkan disajikan sbb:

\begin{tabular}{|c|c|c|c|c|c|}
\hline No & Variabel & Definisi operasional & $\begin{array}{c}\text { Cara } \\
\text { pengukuran }\end{array}$ & $\begin{array}{c}\text { Kriteria } \\
\text { pengukuran }\end{array}$ & Skala \\
\hline \multicolumn{6}{|c|}{ Data yang dikumpulkan dari ibu } \\
\hline 1 & Tiroksin bebas & $\begin{array}{l}\text { Kandungan tiroksin } \\
\text { bebas dalam serum }\end{array}$ & $\begin{array}{l}\text { Standar } \\
\text { pengambilan } \\
\text { darah }\end{array}$ & $\begin{array}{l}>2,0 \mathrm{ng} / \mathrm{mL} \\
\text { hipertiroidi }\end{array}$ & Rasio \\
\hline 2 & TSH & $\begin{array}{l}\text { Hormon pemacu tiroksin } \\
\mathrm{dlm} \text { serum }\end{array}$ & $\begin{array}{l}\text { Dianalisis dg } \\
\text { Ultra_TSH } \\
\text { method }\end{array}$ & $<0,001 \mu \mathrm{gU} \mathrm{I}$ & Rasio \\
\hline 3. & Hemoglobin & & Cyanmeth & $\begin{array}{l}\text { Anemia }<12,0 \\
\mathrm{mg} / \mathrm{dL}\end{array}$ & rasio \\
\hline \multicolumn{6}{|c|}{ Data yang dikumpulkan dari anak sekolah } \\
\hline 4. & EIU & $\begin{array}{l}\text { Konsentrasi iod dalam } \\
\text { urin anak usia sekolah }\end{array}$ & $\begin{array}{l}\text { Pengambilan } \\
\text { sampel urin pd } \\
\text { AUS }\end{array}$ & $\begin{array}{l}\text { Proporsi } \\
\text { median EIU > } \\
300 \mu \mathrm{l} / \mathrm{L} \\
\text { daerah risiko } \\
\text { hipertiroidi }\end{array}$ & Rasio \\
\hline
\end{tabular}

Data AZB dianalisis secara tabel silang dengan endemisitas daerah menurut endemisitas defisiensi iodium tahun 1998 dan dihitung risikonya. Analisa dilanjutkan dengan stratifikasi untuk memperjelas asosiasi AZB dengan defisiensi iodium. Tebaran (plot) hubungan (korelasi) hemoglobin dan TSH dan fT4 juga dianalisis.

\section{HASIL}

Tabel 1, disajikan karakteristik partispan dengan membandingkan daerah endemik dan non endemik. Endemisitas berdasarkan kriteria pembesaran kelenjar tiroid (gondok, yang dipalpasi) keadaan tahun 1998. Jika dikaji dengan keadaan konsentrasi iodium urin maka semua daerah penelitian bukan lagi daerah endemik defisiensi iodium.

Tabel 1

Karakteristik partisipan

\begin{tabular}{|c|c|c|c|c|}
\hline Karakteristik & \multicolumn{2}{|c|}{ Daerah endemik (n1=46) } & \multicolumn{2}{|c|}{ Daerah non endemik (n2=99) } \\
\hline & Rerata & $95 \% \mathrm{Cl}$ & Rerata & $95 \% \mathrm{Cl}$ \\
\hline Umur partisipan (tahun) & 30,9 (Med: 32) & $29,9-32,0$ & 29,8 (Med:30) & $29,0-30,8$ \\
\hline Pendidikan ibu (tahun) & 9,9 (Med: 9,0) & $8,6-11,1$ & $8,8$ (Med: 9,0$)$ & $8,0-9,1$ \\
\hline Tirotropin, serum (mU/L)* & 1,96 & $1,6-2,4$ & 1,38 (Med:0,77) & $1,1-1,7$ \\
\hline Tiroksin bebas, serum (ng/ & (Med:1,54) & $1,1-1,4$ & 0,98 (Med:0,92) & $0,9-1,0$ \\
\hline $\mathrm{dL})^{* *}$ & 1,29 & $12,2-12,7$ & 12,21 (Med:12,3) & $11,96-12,46$ \\
\hline Hemoglobin (mg/dL) & (Med:1,50) & & 35,7 & \\
\hline$\%$ anemia & 12,45 & & & \\
\hline Konsentrasi iodium dalam & (Med:12,4) & & $211(44-487)$ & \\
\hline & 23,3 & & 1,2 & \\
\hline Median (EIU, $\mu \mathrm{g} / \mathrm{L})$ & & & 24,7 & \\
\hline$\%<100$ & $242(24-880)$ & & & \\
\hline$\%>300$ & 5,0 & & & \\
\hline & 29,6 & & & \\
\hline
\end{tabular}

Keterangan: Rerata (median) $95 \%$ confidence interval; ${ }^{*}$ secara statistik berbeda $(p<0,05) ;{ }^{* *}$ beda sekali $(p<0,001)$ 
Umur ibu, lama memperoleh pendidikan formal, dan rata-rata hemoglobin secara statistik tidak berbeda antara daerah endemik dan non endemik. Umur partisipan berkisar di 30 tahun dan pendidikan tamat SMP atau sederajat. Hal ini cukup memberi gambaran kemajuan sosial di daerah penelitian. Hal yang cukup menarik perhatian adalah proporsi AZB yang 12,4 persen lebih tinggi di daerah non endemik dibandingkan dengan daerah endemik, walaupun rata-rata hemoglobin secara statistik tidak berbeda. Perbedaan proporsi anemia yang cukup besar ternyata tidak memperjelas adanya hubungan antara anemia dengan endemisitas defisiensi iodium (OR=0,24-1,24; lihat Tabel 2).

Tabel 2

Anemia di daerah penelitian

\begin{tabular}{|l|r|r|r|}
\hline \multirow{2}{*}{ Anemia $(\mathrm{Hb}<12,0)$} & \multicolumn{2}{|c|}{ endemisitas } & \multicolumn{1}{c|}{ Total } \\
\cline { 2 - 4 } & endemik & non-endemik & \\
\hline Anemia & 10 & 35 & 45 \\
& $23.3 \%$ & $35.7 \%$ & $31.9 \%$ \\
Tidak anemia & 33 & 63 & 96 \\
& $76.7 \%$ & $64.3 \%$ & $68.1 \%$ \\
\hline Total & 43 & 98 & 141 \\
\hline & $100.0 \%$ & $100.0 \%$ & $100.0 \%$ \\
\hline
\end{tabular}

$\mathrm{OR}=0,55(0,24-1,24)$

Di kedua daerah penelitian, konsentrasi hormon tirotropin dalam serum dan tiroksin bebas dalam kisaran normal dengan median/ rata-rata tertekan berada pada limit bawah, namun antara daerah non endemik dan endemik berbeda (masing-masing $p=0,023$ untuk TSH dan $p=0,000$ untuk tiroksin bebas). Hal ini menunjukkan adanya hipertiroidi sub-klinik karena konsumsi iodium yang mulai berlebih seperti yang ditunjukkan pada konsentrasi iodium dalam urin yang melebihi $200 \mu \mathrm{g} / \mathrm{L}$. Median EIU 242匹g/L dan 211 [g/L dengan proporsi di atas $300 \mathrm{gg} / \mathrm{L}, 29,6$ dan 24,7 persen masingmasing untuk daerah endemik dan nonendemik. Hal ini harus diwaspadai, sebab dalam masa 5-10 tahun mendatang dapat terjadi semakin banyak kejadian hipertiroidi yang berdampak pula pada kasus hipotiroidi. 


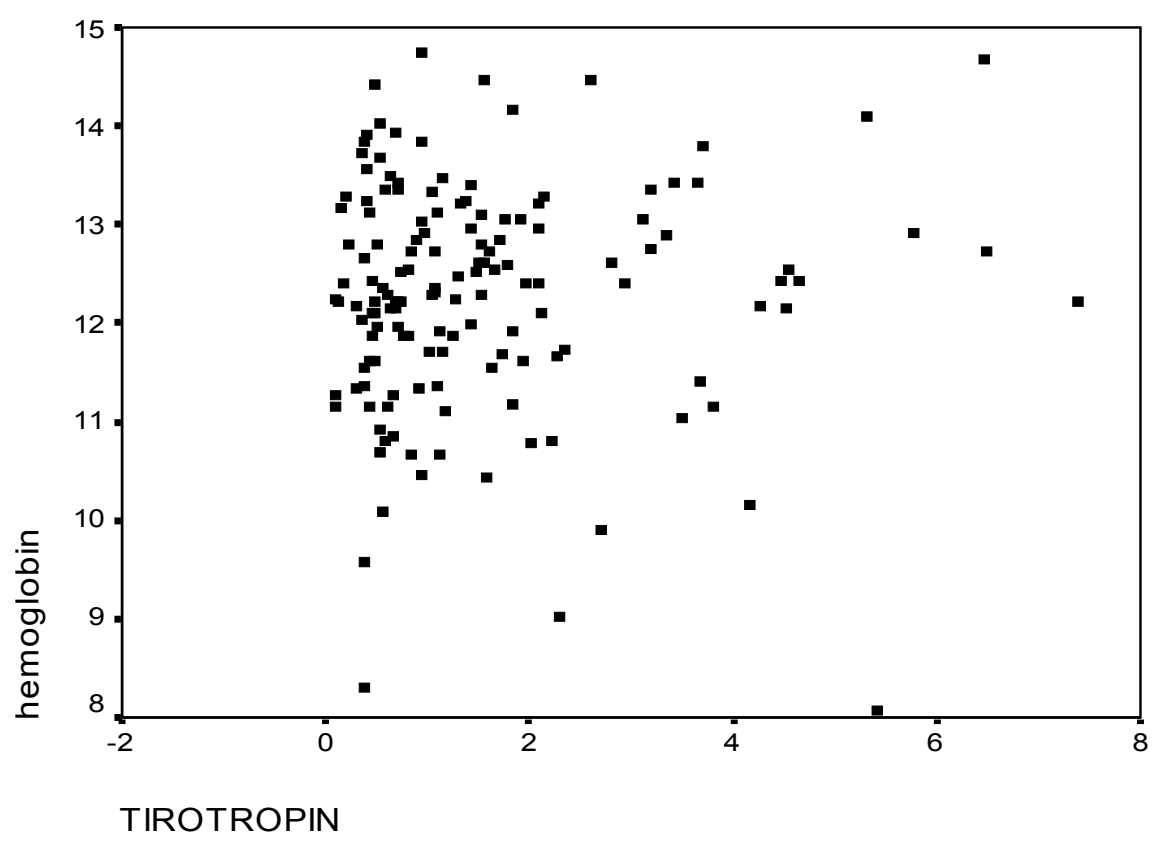

koefisien korelasi Spearman $(R h o)=0,072$

Grafik 1

Tebaran Hubungan hemoglobin (mg/dL) dengan hormon tirotropin (TSH, mU/L) dalam serum

Konsentrasi hemoglobin dan hormon tirotropin dalam penelitian ini tidak memberikan gambaran hubungan antara keduanya baik sebagai marker individu (grafik 1) maupun marker wilayah (Tabel 3).
Hubungan secara individu memberikan koefisien korelasi Rho sebesar 0,072 dan sebagai marker wilayah memberikan rasio odd (OR) sebesar 0,207-2,25

Tabel 3

Hubungan anemi dengan hipotiroidi

\begin{tabular}{|l|r|r|r|}
\hline \multirow{2}{*}{ Anemia $(\mathrm{Hb}<12,0)$} & \multicolumn{2}{|c|}{ Hipo } & \multicolumn{1}{c|}{ Total } \\
\cline { 2 - 4 } & \multicolumn{1}{|c|}{ hipo } & tidak hipo & \\
\hline Anemia & 4 & 41 & 45 \\
& $8.9 \%$ & $91.1 \%$ & $100.0 \%$ \\
Tidak anemia & 12 & 84 & 96 \\
& $12.5 \%$ & $87.5 \%$ & $100.0 \%$ \\
\hline Total & 16 & 125 & 141 \\
\hline & $11.3 \%$ & $88.7 \%$ & $100.0 \%$ \\
\hline OR $=0,68(0,207-2,25)$ & & & \\
\hline
\end{tabular}

Demikian pula, anemia tampak tidak memberikan hubungan dengan dampak defisiensi iodium (Tabel 4). Rasi odd yang diperoleh sebesar $\mathrm{OR}=0,54-2,30$. 
Tabel 4

Asosiasi anemia dengan gondok di daerah penelitian

\begin{tabular}{|l|r|r|r|}
\hline \multirow{2}{*}{ GONDOK } & \multicolumn{2}{|c|}{ anemi <12,0 } & \multicolumn{1}{c|}{ Total } \\
\cline { 2 - 4 } & \multicolumn{1}{|c|}{ anemi } & tidak anemi & \\
\hline Gondok & 18 & 36 & 54 \\
& $33.3 \%$ & $66.7 \%$ & $100.0 \%$ \\
Tidak gondok & 27 & 60 & 87 \\
& $31.0 \%$ & $69.0 \%$ & $100.0 \%$ \\
\hline Total & 45 & 96 & 141 \\
\hline & $31.9 \%$ & $68.1 \%$ & $100.0 \%$ \\
\hline $\mathrm{P}=0,776 ;$ OR=1,11 $(0,54-2,30)$ & \multicolumn{3}{|c}{}
\end{tabular}

\section{BAHASAN}

Peran zat besi terhadap neuropsikomotor (gerak motorik kasar, gerak motorik halus, kognitif dan kecerdasan (IQ)) belum begitu jelas terutama pada tingkat molekuler ${ }^{(27)}$. Tingkat keparahan defisiensi zat besi dapat berpengaruh terhadap peran tersebut ${ }^{(19,28,29)}$. Intervensi zat besi pada ibu hamil dapat saja berpengaruh terhadap status zat besi/ anemia namun ternyata belum tentu berpengaruh terhadap bayi yang dilahirkan ${ }^{(28,30)}$. Demikian pula peran zat gizi lain baik mikronutrien maupun makro nutrien. Misalnya peran vitamin A dalam peningkatan absorbsi zat besi sehingga menaikkan status zat besi termasuk perbaikan prevalensi anemia $^{(31)}$. Kajian lonotti $(2007)^{32}$ terhadap 26 penelitian intervensi zat besi pada anak di bawah usia lima tahun (balita) yang dirancang dengan 'randomized controlled trial-double blind' disimpulkan bahwa suplementasi zat besi dapat meningkatkan status zat besi dan memperbaiki perkembangan gerak motorik dan kognitif. Namun kesimpulan ini perlu disikapi secara hati-hati terutama apakah penelitian yang masuk dalam kajian tersebut sebagai pengobatan (partisipan defisiensi zat besi/ anemia), tujuan penelitian dan karakteristik partisipan (misalnya kelompok umur), jenis intervensi yang diberikan, keterbatasan biomarker ${ }^{(33)}$ dan marker perkembangan gerak motorik dan kognitif yang digunakan.

Dalam penelitian ini hubungan antara iodium dengan zat gizi besi tidak ditemukan, baik secara makro (daerah defisiensi iodium dengan anemia) maupun secara mikro (korelasi konsentrasi antara hemoglobin dengan hormon tirotropin). Eftekhari (2005) dalam penelitian intervensi zat gizi besi dan iodium per oral selama 12 minggu dengan rancangan RCT pada remaja wanita tidak menemukan perbedaan efek pada hormon tirotropin dan tiroksin bebas. Perubahan konsentrasi iodium hanya ditemukan pada kelompok yang diberi perlakuan pemberian iodium dan tidak ada perbedaan pada kelompok lainnya termasuk kontrol. Hess (2002) dalam penelitian intervensi zat gizi besi dan iodium 20 minggu pada anak sekolah 5-11 tahun dengan rancangan kelompok intervensi dan placebo di Cote d'Ivoire, menyimpulkan peningkatan efikasi iodium setelah pemberian zat gizi besi. Namun perlu dicatat bahwa penelitian ini mungkin bias karena pemberian iodium diberikan hanya pada sebagian anak; demikian pula pengukuran juga tidak pada semua anak walaupun dilakukan secara random.

Penelitian ini dilaksanakan dengan rancangan potong-lintang (kroseksional), sehingga mempunyai banyak kelemahan dalam menyimpulkan hasil analisis hubungan antar dua variabel. Konsumsi zat besi dan keadaan awal dari status zat besi ibu WUS partisipan sangat berpengaruh terhadap perubahan cadangan zat besi, tetapi dalam penelitian ini data tersebut tidak tersedia. Perbedaan yang cukup besar proporsi anemia di NDE lebih besar di DE 
mungkin disebabkan faktor-faktor yang belum dikumpulkan dalam penelitian ini. Ekses konsumsi iodium mungkin berpengaruh terhadap perbedaan prevalensi anemia di daerah replete dan non endemik.

Dua langkah awal proses sintesa hormon tiroid dikatalisa oleh TPO dan tergantung ketersediaan $\mathrm{Fe}$. Jadi jika seseorang menderita defisiensi anemia/zat besi (AZB/DZB), hormon tiroid tidak terbentuk, akibatnya konsentrasi T4 dan T3 sedikit di dalam plasma, yang kemudian memicu kenaikan konsentrasi TSH. Penderita anemia menyerap iodium lebih sedikit dibanding anak normal (2). Dalam penelitian ini, dihadapkan pada fenomena di daerah non endemik defisiensi iodium (NDE) yang penderita anemianya lebih banyak, serum TSH dan tiroksin bebasnya lebih rendah dibandingkan dengan kondisi anemia, TSH dan fT4 partisipan di daerah endemik (DE). Hal ini berlawanan dengan teori di atas. Tampaknya dalam penelitian ini status iodium partisipan dalam keadaan transisi ( TSH rendah fT4 juga rendah, yang seharusnya keadaan terjadi berlawanan TSH rendah fT4 tinggi atau sebaliknya) karena konsumsi iodium yang berlebih (EIU>200 $\mu \mathrm{g}$ / L)

Status fungsi iodium terutama konsentrasi TSH dalam serum yang lebih rendah di NDE daripada DE menunjukkan keadaan sub klinik hipertiroidi. Dalam keadaan demikian, iodium terakumulasi pada kelenjar tiroid. lodium yang ekses di dalam kelenjar tiroid dapat mengakibatkan fenomena proses 'Wolff-Chaikoff" terjadi, yaitu proses kejenuhan influks iodium ke dalam kelenjar tiroid. Proses ini berpengaruh pada aktivitas enzim TPO (tiroid peroksidase) dalam pembentukan hormon tiroid. Pada waktu iodium tersedia dalam keadaan normal, enzim TPO aktif dan hormon tiroid terjaga dalam range normal. Kemudian ketika penyerapan iodium dalam kelenjar meningkat, aktivitas TPO meningkat dan kebutuhan zat besi juga meningkat. Seiring dengan hal itu penyerapan zat besi meningkat. Ketika proses penyerapan iodium seolah-olah berhenti, aktivitas TPO menurun.

\section{KESIMPULAN DAN SARAN}

Dalam penelitian ini tidak ditemukan hubungan antara anemia zat gizi besi dengan status iodium baik secara makro maupun secara mikro. Proporsi penderita anemia yang lebih besar di daerah non endemik dibandingkan mantan (replete) endemik defisiensi iodium masih perlu penelitian lebih lanjut.

\section{UCAPAN TERIMA KASIH}

Penulis mengucapkan terimakasih kepada para partisipan yang telah bersedia terlibat dalam penelitian ini. Rasa terimakasih setulusnya disampaikan kepada para anggota peneliti lain atas dedikasinya dalam penelitian ini. Penulis mohon maaf, tidak semua nama peneliti dicantumkan dalam tulisan ini, namun mungkin dalam tulisan lain. Rasa hormat dan terimakasih penulis sampaikan kepada mitra bestari dan redaksi majalah ini atas masukan yang diberikan.

\section{RUJUKAN}

1. Etcheverry $P$, Griffin IJ, and Abrams SA. Micronutrient deficiencies: New Solution to a seemly irresolvable problem. Havard Healyh Policy Review 2005;6(1):77-86

2. Hess, SY. Interaction between iodine and iron deficiencies. [Doctoral dissertation]. Swiss Federal institute of technology Zurich. Diss ETH No 15002. 2003. pp 46-52

3. Indonesia. Departemen Kesehatan. Gizi dalam angka sampai tahun 2002. Jakarta: Departemen Kesehatan. 2003

4. Murray-Kolb LE, Beard JL. Iron treatment normalizes cognitive function in young women. AJCN 2007;85:778-87

5. Graham-McGregor S, Ani C. A Review studies on the effect of iron deficiency on cognitive development in children. $\mathrm{J}$ Nutr 2001;131:649S-66S 
6. Delange F, de Benoist, Pretell E, Dunn JT. Iodine deficiency in the world : where do we stand at the turn of the century. Thyroid 2001;11:437-47

7. Hetzel BS, Delange F, Dunn JT, Ling J, Mannar V, Pandav C [Eds]. Toward the global elimination of brain damage due to iodine deficiency. Oxford Univercity Press. New Delhi. 2004.

8. Boyages SC, Collins JK, Maberly GF, Jup JJ, Morris J, Eastman CJ. lodine impairs intellectual and neuromotor development in apparently normal person. Med J Aust 1989; 150:676-682.

9. Ma T, Lian ZC, Qi SP, Heinz ER, DeLong GR. Magnetic resonance imaging of brain and the neuromotor development in endemic cretinism. Ann Neurol 1993;34:91-94

10. Vermiglio F, LoPresti VP, Argentina GS, Finocchiaro MD, Gullo D, Trimarchi $F$. Maternal hypothyroxinemia during the first half of gestation in an iodine deficient area with endemic cretinism and related disorder. Clin Endocrinol 1995;42:409-15

11. Tiwari BD, Godbole MM, Chatopadhyay, Mandal A, Mithal A. Learning disabilities and poor motivation to achieve due to prolonged iodine deficiency. AJCN 1996;63:782-6

12. Martinez-Galan JR, Pedraza $P$, Santacana M, delRey FE, deEscobar GM, Ruiz-Marcos A. Early effect of iodine deficiency on radial glial cells of hippocampus of the rat fetus. J clin Invest 1997;99:2701-9.

13. Klein RZ, Mitchell ML. Maternal hypothyroidism and child developmenta review. Horm Res 1999;52:55-9

14. Knipper M, Zinn C, Maier $\mathrm{H}$, Praetorius $M$, Rohbock K, Kopschall I, Zimmermann U. Thyroid hormone deficiency before the onset of hearing cause irreversible damage to peripheral and central auditory systems. J Neuro Physiol 200;83:3101-12
15. Chan S, Kilby MD. Thyroid hormone and central nervous system development- a review. J Endocrinol 2000;165:1-8

16. Zimmermann MB, Connolly K, Bozo M, Bridson J, Rohner F, Grimci L. Iodine supplementation improves cognition in iodine-deficient schoolchildren in Albania: a randomized, controlled double blind study. AJCN 2006:83:10814

17. Zimmermann MB, Wegmuller R, Zeder C, Chaouki N, Beibinger R, Hurrel RF et al Triple fortification of salt with microcapsules of iodine, iron and vitamin A. Am J Clin Nutr 2004;80:128390

18. Zimmermann MB, Zeder $\mathrm{C}$, Chaouki $\mathrm{N}$, Torresani T, Hurrel RF. Dual fortification of salt with iodine and microcapsulated iron: a randomized, double-blind, control trial in Moroccan schoolchildren. Am J Clin Nutr 2003;77: 425-32

19. Hess SJ, Zimmermann MB, Adou P, Torresani T, Hurrel RF. Treatment of iron deficiency in goitrous children improves the efficacy of iodized salt in Cote d'lvoire. Am J Clin Nutr 2002;75:743-8

20. Hawkes WC, Keim NL. Dietary Selenium intakes modulates thyroid hormone and energy metabolism in men. J Nutr 2003;133:3443-8

21. Hotz CS,Fitzpatrick DW, Trick KD, L'Abbe MR. Dietary lodine and Selenium Interact to effect thyroid hormone metabolism of rats. J Nutr 1997;127:1214-8

22. Aihara $K$, Nishi $Y$, Hatano $S$, Kihara $M$, Yoshimitsu K, Takeichi N, Ito T, Ezaki $H$, Usui T. Zinc, copper, manganese, and selenium metabolism in thyroid disease. Am J Clin Nutr 1984;40:26-35

23. Dahro AM, Permaesih D, Rosmalina Y. Dampak suplementasi yodium pada ibu atau bayi terhadap status yodium, status gizi dan kadar hematoglobin bayi. Penelit. Gizi Makan 1997: 110-18 
24. Rajagopalan S, Vinokumar M. Effect of salt fortified with iron and iodine on the hemoglobin levels and productivity of tea pickers. FNB 2000;323-29

25. Hurrel RF. Fortification: overcoming and practical barriers. J Nutr 2002;132:806S-12S

26. Zimmermann MB, Adou P, Zeder C, Torresani T, Hurrel RF. Persistence of goitre despite oral iodine supplementation in goitrous children with iron deficiency anemia in the Cote d'Ivoire. Am J Clin Nutr 2000;71:88-93

27. McCann JC and Ames BN. An overview of evidence for casual relation between iron deficiency during development and deficits in cognitive or behavioral function. AJCN 2007; 85:931-45

28. Zhou SJ, Gibson RA, Crowther CA, Baghurst $P$, Makrides $M$. Effect of iron supplementation during pregnancy on the intelligence quotient and behaviour of children at $4 \mathrm{y}$ of age: long-term follow-up of a randomized controlled trial. AJCN 2006;83:1112-7
29. Murray-Kolb LE, Beard JL. Iron treatment and $\mathrm{Fe}$-Cognititive Function AJCN 2007;85:778-87

30. Muslimatun S, Schmidt MK, West CE, Schultink W, Hautvast JGAJ, Karyadi D. Weekly vitamin $A$ and iron supplementation during pregnancy increases vitamin A concentration of breast milk but not iron status in Indonesian lactating women. J Nutr 2001;131:2664-9

31. Zimmermann MB, Beibinger R, Rohner $F$, Dib A, Zeder C, Hurrel RF, et al. Vitamin $A$ supplementation in children with poor vitamin $A$ and iron status increases erythropoietin and hemoglobin concentrations without changing total body iron. AJCN 2006;84:580-6.

32. Ionnotti LL, Tielsch JM, Black MM, Black RE. Iron supplementation in early childhood: health benefits and risks. AJCN 2007;84:1261-76

33. Potischman N. Biologic and Methodologic issues for nutritional biomarkers. J Nutr 2003: 875S-80S 